\title{
CHRONAXIMETRIC EXAMINATIONS IN B AVITAMINOSIS DURING PREGNANCY
}

\author{
By F. H. LEWY \\ (From the Gastro-Intestinal Section of the Medical Clinic, Hospital of the University of \\ Pennsylvania, Philadelphia)
}

(Received for publication February 26, 1937)

In 1929 Lewy and Weisz (1) stated that persons having contact with lead exhibited an increase in the excitability of the nerves and muscles which could be demonstrated chronaximetrically several months before clinical symptoms appeared. That this method might prove valuable as a means of detecting preclinical evidence of peripheral neuritis due to vitamin $B$ deficiency was suggested in 1934 when Lane and Lewy (2) encountered chronaximetric changes in a group of factory workers taking a vitamin $\mathrm{B}$ deficient diet but in whom clinical evidence of vitamin B deficiency had not yet developed. To test further the value of this method in demonstrating early vitamin B deficiency, repeated chronaximetric examinations were made upon the group of pregnant women described by Elsom (3) in the preceding paper. Examinations were carried out early in the observation of these subjects, after addition to the diet of yeast or of liver extract and following delivery. The results of these examinations are given in the present communication.

\section{METHODS OF STUDY}

Chronaximetric examinations were made at each visit. Unless otherwise stated the radial nerve was used. The tests were made independently of the other procedures carried out so that not until after the delivery of each subject was this examiner aware of the associated observations made by Elsom (3).

The theory and technique of chronaximetric measurement have been described in detail elsewhere (4). Suffice it to state here that chronaxie is a measurement of the time a current of doubled threshold value must pass through a tissue in order to elicit the first muscle twitch or the first sensation. In the present examinations the time was determined with currents not only double the threshold value, but also with five or six more values.
From the information so obtained, a strength duration curve could be constructed characteristic of the nerve irritability. It is believed that repeated examinations of this type are necessary to obtain an accurate picture of the chronaxie for each individual.

\section{RESULTS}

In Table I are given the results of chronaximetric examinations in eight subjects as compared with clinical and blood changes observed in these persons at various times throughout the period of observation.

Subject 1 is an example of the fact that the chronaxie may become abnormal before clinical evidence of vitamin B deficiency had been detected. This was indicated by overexcitability of the radial nerve. Two weeks after the administration of brewer's yeast the chronaxie again became normal at the same time that clinical evidence of deficiency disappeared. Following delivery, this patient failed to continue the prescribed yeast and, when examined three weeks later, the radial nerve was again found overexcitable although no clinical evidence of deficiency was as yet manifest.

In Subject 8 likewise chronaximetric changes preceded the appearance of clinical evidence of deficiency. In this individual both clinical and hematological changes were more extensive than in Subject 1. This severity was reflected in the chronaximetric observations by a change from overexcitability of the radial nerve to a condition of underexcitability, a phenomenon which is known to occur in more advanced stages of peripheral neuritis. Following the inauguration of vitamin B therapy gradual return toward normal was noted in all types of observations so that at the time of delivery all examinations were negative.

Observations similar to those described above were made in each of the eight women studied. 
Correlation between clinical, hematological and chronaximetric studies was close in each instance. However, the nerve once degenerated, i.e., underexcitable, a longer time was required for its restitution than for the blood regeneration.

\section{COMMENT}

The present investigations have shown that electric irritability of the peripheral nerves occurred even before clinical changes were noted in some of eight pregnant women taking diets which proved to be deficient in vitamin B. Upon the addition of yeast or of liver extract to the diet the neuropathy, as detected by chronaximetric examination, improved concomitant with clinical improvement. There was correlation also between the severity of clinical evidence of deficiency and the degree of chronaximetric change in the peripheral nerves examined.

It is considered wise to emphasize the desirability of determining the whole strength duration curve for nerve or muscle at each examination. This is particularly important in detecting the first stages of nerve degeneration and the last stages of regeneration. Two further points are worthy of mention. We examined the chronaxie of the motor system as we wished to be independent of the subjective statements of the patients. There is, however, little doubt that, in these patients as in lead poisoning, the chronaxie of the sensory system should give a still earlier and finer indication of the beginning abnormality (Altenburger (5)). And finally, although in the present investigation the radial system was selected as the site of examination to avoid the objections which might arise from a possible pressure on the sciatic nerve, it is believed that the peroneal or the sciatic systems are preferable sites for examination since subjective and objective symptoms in our patients were prominent in the legs and very infrequent in the arms. The

TABLE. I

Results of chronaximetric examinations

\begin{tabular}{|c|c|c|c|c|c|c|c|c|c|c|}
\hline \multirow[b]{2}{*}{$\underset{\text { ber }}{\text { Case }}$} & \multirow[b]{2}{*}{ Date } & \multirow[b]{2}{*}{ Diet } & \multicolumn{2}{|c|}{ Changes in } & \multicolumn{2}{|c|}{ Sensory disturbances } & \multicolumn{3}{|c|}{ Chronaxie } & \multirow[b]{2}{*}{ Excitability $\ddagger$} \\
\hline & & & Blood & $\begin{array}{l}\text { Clini- } \\
\text { cal } \\
\text { mani- } \\
\text { festa- } \\
\text { tions }\end{array}$ & Vibratory sense & $\begin{array}{l}\text { Other signs and } \\
\text { symptoms }\end{array}$ & Volt & $\sigma^{*}$ & vct & \\
\hline \multirow[t]{7}{*}{1.} & February 9 & Without added vitamin $B$ & $\mathbf{0}$ & $\mathbf{0}$ & Normal & 0 & 80 & 0.76 & 7.8 & Normal \\
\hline & March 2 & Without added vitamin B & $\mathbf{0}$ & $\mathbf{0}$ & Normal & $\mathbf{0}$ & 80 & 0.36 & 5.4 & Increased \\
\hline & March 16 & Without added vitamin $B$ & $\mathbf{0}$ & $\mathbf{0}$ & Normal & $\begin{array}{l}\text { Radial nerves tender to } \\
\text { pressure. Hyperpathy } \\
\text { in area of cutaneous } \\
\text { femoral lateral nerve } \\
\text { and of } 2 \mathrm{~d} \text { sacral root }\end{array}$ & 65 & 0.28 & 4.5 & Increased \\
\hline & March 25 & Without added vitamin B & + & + & Normal & $\begin{array}{l}\text { Radial nerves tender to } \\
\text { pressure. Hyperpathy } \\
\text { in area of cutaneous } \\
\text { femoral lateral nerve } \\
\text { and of } 2 \mathrm{~d} \text { sacral root }\end{array}$ & & & & \\
\hline & April 13 & $\begin{array}{l}\text { Supplemented with yeast } \\
\text { since April } 13\end{array}$ & + & + & Diminished & $\begin{array}{l}\text { Radial nerves tender to } \\
\text { pressure. Hyperpathy } \\
\text { in area of cutaneous } \\
\text { femoral lateral nerve } \\
\text { and of 2d sacral root }\end{array}$ & 70 & 0.40 & 5.3 & Increased \\
\hline & April 27 & Supplemented with yeast & $\mathbf{0}$ & $\mathbf{0}$ & Slightly diminished & $\mathbf{0}$ & 90 & 0.48 & 6.6 & Normal \\
\hline & May 20 & $\begin{array}{l}\text { After delivery without } \\
\text { added vitamin B }\end{array}$ & $\mathbf{0}$ & $\mathbf{0}$ & Normal & $\mathbf{0}$ & 100 & 0.24 & 4.7 & Increased \\
\hline \multirow[t]{2}{*}{2.} & May 4 & Without added vitamin $B$ & ++ & + & ++ & $\mathbf{0}$ & 110 & 0.72 & 8.9 & $\begin{array}{l}\text { Superior limit } \\
\text { of normal }\end{array}$ \\
\hline & June 26 & Supplemented with yeast & $\mathbf{0}$ & $\mathbf{0}$ & $\mathbf{0}$ & $\mathbf{0}$ & 75 & 0.68 & 6.9 & Normal \\
\hline \multirow[t]{3}{*}{3.} & April 13 & Without added vitamin $B$ & $+t+$ & +++ & ++ & $\begin{array}{l}\text { Hyperpathy in area of } \\
\text { right 2d sacral root; } \\
\text { numbness of left arm }\end{array}$ & 80 & 1.20 & 9.8 & Decreased \\
\hline & May 27 & $\begin{array}{l}\text { Supplemented with yeast } \\
\text { since April } 14\end{array}$ & 0 & 0 & 0 & $\mathbf{0}$ & \multicolumn{2}{|c|}{$\begin{array}{l}\text { Discontinu- } \\
\text { ous curve }\end{array}$} & $\begin{array}{r}6.5 \\
12.5\end{array}$ & $\begin{array}{l}\text { Normal } \\
\text { Decreased }\end{array}$ \\
\hline & June 24 & $\begin{array}{l}\text { After delivery without } \\
\text { added vitamin B }\end{array}$ & & & & $\begin{array}{l}\text { Numbness and weakness } \\
\text { of left arm }\end{array}$ & 105 & 2.00 & 14.5 & Decreased \\
\hline
\end{tabular}


TABLE I-Continued

\begin{tabular}{|c|c|c|c|c|c|c|c|c|c|c|}
\hline \multirow{2}{*}{$\begin{array}{c}\text { Case } \\
\text { num- } \\
\text { ber }\end{array}$} & \multirow[b]{2}{*}{ Date } & \multirow[b]{2}{*}{ Diet } & \multicolumn{2}{|c|}{ Changes in } & \multicolumn{2}{|c|}{ Sensory disturbances } & \multicolumn{3}{|c|}{ Chronaxie } & \multirow[b]{2}{*}{ Excitability $\ddagger$} \\
\hline & & & Blood & $\begin{array}{c}\text { Clini- } \\
\text { cal } \\
\text { mani- } \\
\text { festa- } \\
\text { tions }\end{array}$ & Vibratory sense & $\begin{array}{l}\text { Other signs and } \\
\text { 8ymptoms }\end{array}$ & Volt & $\sigma^{*}$ & vct & \\
\hline \multirow[t]{4}{*}{4.} & April 6 & Without added vitamin B & $\mathbf{0}$ & $\mathbf{0}$ & $\mathbf{0}$ & $\mathbf{0}$ & 85 & 0.40 & 5.3 & Increased \\
\hline & May 4 & Without added vitamin $B$ & +++ & $+t$ & + & $\mathbf{0}$ & 90 & 0.40 & 5.2 & Increased \\
\hline & May 29 & $\begin{array}{l}\text { Supplemented with yeast } \\
\text { since May } 5\end{array}$ & ++ & $\mathbf{0}$ & $\mathbf{0}$ & $\begin{array}{l}\text { Left leg sleepy. Left } \\
\text { peroneal nerve tender } \\
\text { to pressure }\end{array}$ & \multicolumn{2}{|c|}{$\begin{array}{l}\text { Discontinu- } \\
\text { ous curve }\end{array}$} & $\begin{array}{r}8.8 \\
10.0\end{array}$ & $\begin{array}{l}\text { Top normal } \\
\text { Decreased }\end{array}$ \\
\hline & June 17 & $\begin{array}{l}\text { Supplemented with yeast } \\
\text { since May } 5\end{array}$ & + & $\mathbf{0}$ & $\mathbf{0}$ & $\mathbf{0}$ & 80 & 0.80 & 6.6 & Normal \\
\hline \multirow[t]{3}{*}{5.} & April 24 & Without added vitamin B & +++ & +++ & ++ & $\mathbf{0}$ & 60 & 0.60 & 6.0 & $\begin{array}{l}\text { Inferior limit of } \\
\text { normal }\end{array}$ \\
\hline & May 11 & Supplemented with yeast & + & + & $\mathbf{0}$ & & & & & \\
\hline & June 12 & After delivery & & & & $\mathbf{0}$ & 90 & 0.60 & 7.3 & Normal \\
\hline \multirow[t]{2}{*}{6.} & April 15 & Without added vitamin B & +++ & + & + & $\mathbf{0}$ & 60 & 1.87 & 10.5 & Decreased \\
\hline & & Supplemented with yeast & $\mathbf{0}$ & $\mathbf{0}$ & $\mathbf{0}$ & & & & & \\
\hline \multirow[t]{2}{*}{7.} & June 6 & Without added vitamin $B$ & $++t$ & +++ & + & $\begin{array}{l}\text { Hyperpathy in area of } \\
2 \mathrm{~d} \text { sacral root }\end{array}$ & 60 & 4.80 & 17.0 & Decreased \\
\hline & June 26 & Supplemented with yeast & + & $\mathbf{0}$ & $\mathbf{0}$ & $\mathbf{0}$ & \multicolumn{2}{|c|}{$\begin{array}{l}\text { Discontinu- } \\
\text { ous curve }\end{array}$} & $\begin{array}{r}7.7 \\
14.5 \\
\end{array}$ & $\begin{array}{l}\text { Normal } \\
\text { Decreased }\end{array}$ \\
\hline \multirow[t]{9}{*}{8.} & February 6 & Without added vitamin B & $\mathbf{0}$ & $\mathbf{0}$ & Normal & $\mathbf{0}$ & 75 & 0.68 & 7.1 & Normal \\
\hline & March 9 & Without added vitamin B & $\mathbf{0}$ & $\mathbf{0}$ & Normal & $\mathbf{0}$ & 80 & 0.36 & 5.4 & Increased \\
\hline & March 20 & Without added vitamin B & $\mathbf{0}$ & $\mathbf{0}$ & Normal & \multirow{2}{*}{$\begin{array}{l}\text { Hyperpathy in area of } \\
2 \mathrm{~d} \text { sacral root }\end{array}$} & 50 & 0.48 & 4.9 & Increased \\
\hline & April 13 & Without added vitamin B & +++ & + & Normal & & & & & \\
\hline & April 27 & Without added vitamin B & +++ & + & Normal & Plus numbness in left leg & 90 & 0.84 & 9.3 & Decreased \\
\hline & May 4 & Supplemented with yeast & +++ & + & Slightly diminished & Plus numbness in left leg & & & & \\
\hline & May 27 & Supplemented with yeast & $+t$ & $\mathbf{0}$ & Normal & Less discomfort & \multicolumn{2}{|c|}{$\begin{array}{l}\text { Discontinu- } \\
\text { ous curve }\end{array}$} & $\begin{array}{r}7.0 \\
10.0\end{array}$ & $\begin{array}{l}\text { Normal } \\
\text { Decreased }\end{array}$ \\
\hline & June 6 & Supplemented with yeast & + & $\mathbf{0}$ & Normal & Less discomfort & 75 & 0.42 & 5.5 & Increased \\
\hline & June 17 & Supplemented with yeast & $\mathbf{0}$ & $\mathbf{0}$ & Normal & 0 & 80 & 0.80 & 6.7 & Normal \\
\hline
\end{tabular}

* $\sigma=1 / 1000$ second; normal range about 0.44 to $0.8 \sigma$.

$\dagger \mathrm{vc}=$ Vertex coördinate the normal of which is between 6 and 9 for the examined nerve muscle apparatus.

$\ddagger$ Examined at the muscularis extensor digitorum commuris and on the radial nerve.

same affinity of a noxious agent for the inferior extremities has been noted previously (Tietze (6)) in the neuritis secondary to exposure to carbon disulphide or to methyl bromide.

\section{SUM MARY}

Chronaximetric changes were observed in the radial nerves of a group of pregnant women taking diets which proved to be deficient in vitamin B. These changes often preceded clinical and hematological evidence of vitamin B deficiency.

The degree of peripheral nerve change, as indicated by chronaximetric examination, coincided with the severity of clinical manifestations of deficiency.

Improvement following vitamin B therapy was observed chronaximetrically at the time that clinical improvement was recorded.

\section{BIBLIOGRAPHY}

1. Lewy, F. H., and Weisz, St., Chronaxieuntersuchungen an Bleiarbeitern. Ztschr. f. d. ges. Neurol. u. Psychiat., 1929, 120, 385.

2. Lane, R. E., and Lewy, F. H., Blood and chronaximetric examination of lead workers subjected to different degrees of exposure. A comparative study. J. Indust. Hyg., 1935, 17, 79.

3. Elsom, K. O'Shea, Macrocytic anemia in pregnant women with vitamin B deficiency. J. Clin. Invest., 1937, 16, 463.

4. Lewy, F. H., Strength duration curves of the overexcitable and underexcitable nerve muscle apparatus and some consequences bearing on the clinical application of chronaximetry. Am. J. M. Sc., 1936, 191, 491.

5. Altenburger, H., Sensible Chronaxie. Deutsche Ztschr. f. Nervenh., 1933, 129, 219.

6. Tietze, A., Klinische Beobachtungen z. Methylbromidu. Tetrachlorkohlenstoff-Vergiftung. Arch. f. Gewerbepath. u. Gewerbehyg., 1933, 4, 733. 